\title{
O Alarido das Vidas Marginais na Obra de Chico Buarque
}

The sounds of the marginal lives in Chico Buarque's songs

Resumo:O objetivo deste trabalho é analisar como o compositor Chico Buarque discorre, em inúmeras composições, sobre os desenlaces da vida cotidiana das chamadas classes populares brasileiras e dos personagens que as constituem, potencializando e vitalizando suas narrativas.

Para tanto, partimos do pressuposto que, sob a égide de um discurso historicamente construído, as vozes das classes populares foram, e são, continuamente desqualificadas e ouvidas pelo prisma da falta e da carência.Outrossim, cremos ser possível observar, na obra do artista, uma radical singularidade quanto ao cotidiano desses personagens, promovendo novos olhares sobre seus modos de vida e apresentando alternativas promissoras ao enfrentamento das lógicas naturalizadoras proferidas por discursos hegemônicos. Palavras-Chave: Classes populares, Chico Buarque, estigma, mídia.

Abstract:The objective of this work is to analyze how composer Chico Buarque discourses through numerous pieces of music in the daily life outcome of the so-called Brazilian lower social classes and their characters, powering and vitalizing his narratives.To do so, the work was based on the fact that, under a historically built speech, the lower-class voices have been continuously underrated, as well as listened to through the prism of lack and privation.Likewise, we believe it's possible to notice in the artist's work radical singularity about those characters' everyday life, allowing the arousal of new insights into their way of life and showing promising alternatives to face the naturalizing logic uttered in hegemonic speeches.

Key Words: Lower social classes, Chico Buarque, stigma, mass media.

Rodrigo Moraes

Filiação institucional: Psicólogo, residente em saúde mental do Hospital Psiquiátrico de Jurujuba (Niterói / RJ)
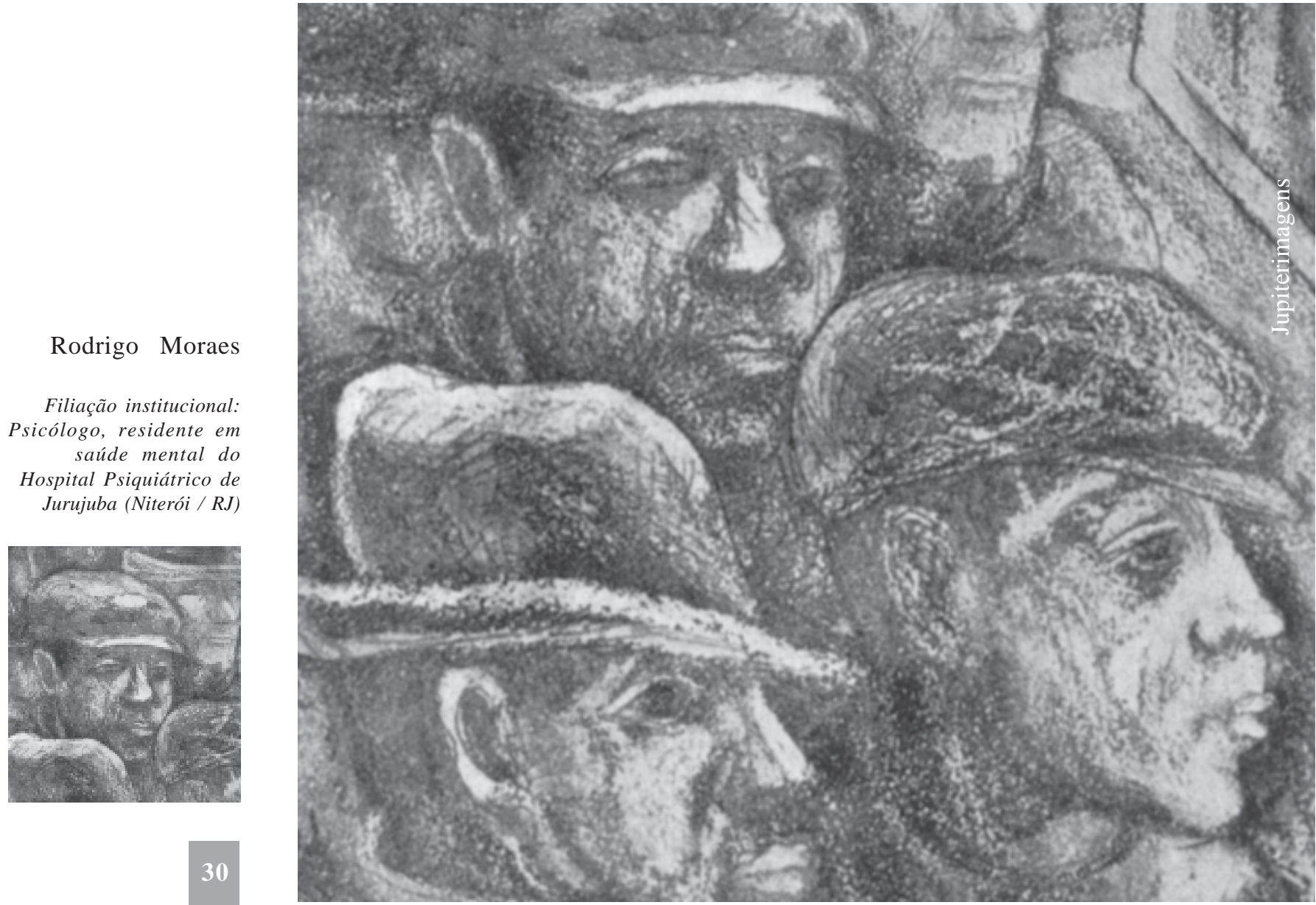
Que contribuições a música popular brasileira pode oferecer-nos para problematizarmos teorias e conceitos abordados exaustivamente na academia? Conceitos tais como exclusão, inclusão, produção de subjetividades, marginalidade, estigmatização, alteridade e tantos outros trazidos à tona, quando o assunto diz respeito às classes menos favorecidas, econômica e socialmente, no Brasil.

A enorme massa de cidadãos brasileiros aí inserida é, há tempos, alvo das mais variadas teorizações e especulações sobre suas vidas e seus destinos. Munida de seus supostamente sólidos referenciais teóricos, mesmo que não pela via de um racionalismo simplificador, estariam as produções teóricas acadêmicas aptas a dar conta das complexas relações sociais que se tecem no cotidiano das classes populares brasileiras? Adiantamos apostar em uma resposta negativa para a pergunta. No entanto, não se trata, aqui, de uma denúncia contra o deficiente arcabouço conceitual acadêmico para lidar com os problemas que se apresentam quando esse assunto se impõe. Acreditamos, inclusive, que a academia nem mesmo possa ter tal pretensão, justamente por tratar-se de um tema jamais esgotável. Sendo assim, que outras ferramentas nos podem ser úteis para lidar com esse assunto? Que parcerias podemos fazer para radicalizar a discussão sobre um problema tão urgente quanto antigo? Sem dúvida, elas existem, e, certamente, os muros das academias não abarcam todas as respostas.

\section{A Arte: Estamos aí Diante de uma Potencial Aliança}

A resposta, no entanto, é ainda um tanto quanto vaga. Quando pensamos no binômio "classe popular" / "manifestação artística", o tipo de expressão a se sobressair é a música, cremos. Por motivos até mesmo elitistas, ela sempre ocupou historicamente um lugar de destaque entre as manifestações culturais advindas dessa parcela da população, e é indubitavelmente a de maior circulação entre esse segmento. Se, por imposição da lógica capitalista de mercado, o acesso aos bens de consumo e produção sempre foi negado às classes populares, no caso da cultura, a situação não se modifica.

Quanto às possíveis articulações que podem ser estabelecidas entre um tipo de manifestação artística popular e o meio acadêmico, mais especificamente com a Psicologia, pensamos que tais atravessamentos não só são perfeitamente viáveis como também extremamente necessários. Cremos, inclusive, que, tanto a Universidade quanto as demais instituições produtoras de saber somente justificam sua existência quando caminham no sentido de promover a aproximação entre sua produção de conhecimento e os diversos segmentos sociais de nosso tempo, quaisquer que sejam, de forma indiscriminada, trazendo, inclusive e preferencialmente, em seu bojo, todos os conflitos e tensões que tais segmentos possam suscitar.

Filiamo-nos, assim, ao pensamento de Novaes (1999, p. 05), que vislumbra a concreta possibilidade de articulação entre as produções das classes subalternas e o ambiente acadêmico supostamente elitista (e que, em certa medida, até justifica essa fama). Procuramos, ainda, através deste trabalho, romper com uma certa estigmatização imputada principalmente à música popular e à poesia quando utilizadas no círculo acadêmico, visto não ser raro observarmos o uso destas meramente como recurso alegórico, um simples enfeite, epígrafes introdutórias de algo culto que se insinua, de um saber elaborado por vir, delegando-as, assim, a um lugar subalterno em relação a um certo ideal de cientificidade ainda não superado.

Mediado por um processo de construção histórica, vigora hoje, no Brasil, um contexto socioeconômico-cultural que prioriza a história dos vencedores em detrimento da história dos vencidos. Realizações fantásticas são demandadas incessantemente, as quais, muitas vezes, surgem sob o signo do herói travestido na imagem do cidadão burguês bem sucedido, construção histórica amplamente disseminada em nosso cotidiano, manifestando-se, como demonstra Coimbra (2001, pp. 29-30),

através da ininterrupta construção de modelos de unidade, de racionalidade, de legitimidade, de justiça, de beleza, de cientificidade (...) [produzindo] subjetividades que nos indicam como nos relacionar, (...) ser e viver dentro de um permanente processo de modelização.

Um dos meios mais sutis, porém não menos violentos, de captura e esquadrinhamento das classes consideradas subalternas foi historicamente sendo operado através da construção e ordenação de um poderoso discurso amparado, sustentado e legitimado por valores científicos, éticos e morais, havendo, concomitantemente, toda uma construção de conhecimento sobre tais classes que, obviamente, confirma as premissas que as subjugam. Contemporaneamente, difundido amplamente pela máquina midiática parcial a serviço de determinados setores governamentais, acadêmicos e da sociedade civil, tais discursos hegemônicos recebem o status de realidade incontestável, compondo-se, assim, as condições

\section{“...através da ininterrupta construção de modelos de unidade, de racionalidade, de legitimidade, de justiça, de beleza, de cientificidade (...) [produzindo] subjetividades que nos indicam como nos relacionar, (...) ser $e$ viver dentro de um permanente processo de modelização".}

Coimbra 
necessárias para o estabelecimento de verdades absolutas sobre a vida de outrem, abordagem que tem, como fim último, a subordinação aos modos majoritários de agir, de pensar, de se pronunciar, de fazer aparecer. Desejos, vontades e anseios podem, a partir de então, ser criados, calados, domesticados ou dissipados. Qualquer uma dessas possibilidades não exclui um processo manipulatório extremamente afinado com os modos contemporâneos de produção capitalista e suas capilarizações.

“A essa 'história oficial', também chamada de 'ótica dos vencedores' opõe-se um outro real com outras verdades,

outras histórias e memórias produzidas por práticas sociais não hegemônicas: as práticas dos que ficaram conhecidos como os 'vencidos'.

Essa 'história marginal'

é forjada pelos diferentes grupos $e$ movimentos sociais nas suas lutas, no seu cotidiano, nas suas resistências e teimosia

- muitas vezes subterrâneas e

invisíveis - em produzir outras maneiras de ser, de viver, outras sensibilidades $e$ percepções, outras formas de existir. Estas, por vezes, são abertamente

desqualificadas ou simplesmente

ignoradas pelas visões dominantes"

Coimbra
Nesse aspecto, a supremacia de determinadas classes sociais sobre outras se engendra, dentre outros fatores, pela imposição de discursos forjados, regidos por instâncias de poder que se autorizam a falar pelos e para os indivíduos. Esse processo de captura acaba por criar massas de indivíduos despersonalizados, falas despotencializadas, histórias de vidas subalternas, narrativas estigmatizadas desde o seu mais embrionário pronunciamento, narrativas sobrepujadas pela supremacia atribuída à história dos vencedores que forjam e manipulam quando, o que e como as falas oriundas das classes marginais ecoarão.

A essa 'história oficial', também chamada de 'ótica dos vencedores' opõe-se um outro real com outras verdades, outras histórias e memórias produzidas por práticas sociais não hegemônicas: as práticas dos que ficaram conhecidos como os 'vencidos'. Essa 'história marginal' é forjada pelos diferentes grupos e movimentos sociais nas suas lutas, no seu cotidiano, nas suas resistências e teimosia - muitas vezes subterrâneas e invisíveis - em produzir outras maneiras de ser, de viver, outras sensibilidades e percepções, outras formas de existir. Estas, por vezes, são abertamente desqualificadas ou simplesmente ignoradas pelas visões dominantes (Coimbra, 2001, p.51).

Como, então, os discursos e histórias de vida dos segmentos economicamente desfavorecidos da sociedade brasileira podem ser apresentados pelo viés da arte - mais especificamente, da música presente na cultura popular? E ainda: o que esses discursos e histórias apresentam de originalidade e complexidade que, via de regra, escapam aos modos doutos de racionalização acerca dessas vidas?

Delimitando metodologicamente este trabalho, debruçamo-nos sobre a análise das composições de um único artista da música popular: Chico Buarque, deixando claro que não se trata de um estudo crítico sobre a obra desse artista. Suas composições serão tão somente utilizadas como ferramenta, um meio para a investigação do tema proposto, sem perder de vista que a obra de vários outros artistas de nossa música se prestaria como fonte de pesquisa para tal assunto. A discografia popular brasileira é extremamente rica nesse aspecto, repleta de compositores que buscam, no dia-a-dia das classes populares, o ingrediente para a criação.

Ao longo das últimas quatro décadas, Chico vem compondo canções onde essas vidas infelizes são apresentadas de uma maneira diferenciada da que nos é ofertada pelo mercado do senso comum. No entanto, seria enganoso dizer que, mesmo em suas composições, essas narrativas de vida surgem de maneira plena, representando, de fato, a realidade onde estão inseridas; cometer-se-ia, assim, um erro grotesco, pelo simples fato de um dos objetivos indiretos deste trabalho ser justamente apontar para a indignidade de se falar pelo e para o outro.

Dono de uma obra extremamente vasta, são muitas as composições de Chico onde podemos colher exemplos dessa riqueza de acontecimentos em que apostamos, rompendo com a narrativa linear da história que amortiza a complexidade dessas vidas marginalizadas, corroborando, assim, a hipótese formulada. Todavia, não se trata de uma tentativa de apropriação intelectual do discurso popular através das letras. Tampouco pretendemos apresentar um radical processo de singularização que desautorize qualquer tentativa de inteligibilidade sobre o cotidiano dessas vidas. Para escapar de uma possível relativização do problema, procuramos, neste trabalho, oferecer condições para que esses discursos falem por si só, potencializando-os pelo caminho de sua própria autenticidade. Em um estudo sobre a malandragem e o samba à época de Getúlio Vargas, Matos (1982, p. 22) afirma:

As letras de samba, por muito tempo, constituíram o principal, senão o único, documento verbal que as classes populares do Rio de Janeiro produziram autônoma e espontaneamente. (...) começam a proliferar estudos, projetos, trabalhos universitários que, muitas vezes, tentam enxergar esses textos, ainda intactos em sua significação, através das lentes teóricas fornecidas pela Teoria da Literatura, a Sociologia, a Psicanálise e outras ciências afins. É, certamente, o caminho mais fácil procurar, apressadamente, enquadrar um objeto desconhecido e estranho em sistemas analíticos com os quais já estamos familiarizados, formas de discurso previamente elaboradas, categorias já testadas.

Neste trabalho, procuramos orientar-nos pela via privilegiada pela autora, e temos como referência seu posicionamento perante a apreensão das composições de samba:

Procurei abdicar de respaldos teóricos que ameaçassem obliterar a especificidade dos textos, 
sem, entretanto, desprezar conceitos cuja aplicação se revelasse simultaneamente eficaz e honesta. De toda maneira, o essencial está dito pelo texto, e não pelos conceitos que a especulação intelectual possa fazer gravitar em torno dele (Matos, 1982, p. 22).

Com uma percepção extremamente aguçada daquilo que está à sua volta, Chico Buarque é capaz de encarnar os mais diversos personagens em sua obra, fazendo-se mulher, operário ou criança. Atento aos acontecimentos do mundo, a temática social sempre foi um dos principais elementos de inspiração para seus trabalhos, revelando a estreita sintonia entre sua obra e a realidade brasileira mais imediata. Seja qual for o canal artístico, na música, no teatro ou na literatura, Chico jamais se afastou muito de um de seus temas prediletos: os marginais, os anti-heróis, os desvalidos, e a estes dedicou inúmeras composições.

São operários em Pedro Pedreiro e Construção, prostitutas em Geni e o Zepelim e Ana de Amsterdam, crianças infratoras em $O$ Meu Guri e Pivete, malandros em Vai Trabalhar Vagabundo e A Volta do Malandro, faxineira clandestina em Iracema Voou. São personagens que compõem o imenso "plano dos bandidos, dos desvalidos", sistematicamente desqualificados em nosso país, cujo acesso a inúmeras esferas da vida social compartilhada lhes é estrategicamente negado, inventando, por isso, outras a todo instante, provando que a vida pode ser mais rica e complexa do que os discursos oficiais tentam impor.

\section{Vidas Sob Suspeita, Corpos sob Controle}

Talvez hoje, mais do que nunca, estejamos vivendo sob a égide de uma sociedade calcada na difusão das normas, disciplinamento das condutas e vigilância dos hábitos regulando nossos comportamentos mais particulares. As estratégias de controle sobre as classes pobres se fortalecem, passando por reestruturações táticas recrudescedoras com o decorrer dos anos. Contemporaneamente, o conceito de periculosidade revela-se como ponto nodal no estudo sobre o tema das classes socialmente marginalizadas e a desqualificação de suas falas e histórias de vida por parte das classes dominantes. O objetivo das leis e políticas públicas vigentes não é, exclusivamente, punir os crimes, mas também evitar a sua ocorrência. De acordo com a noção de periculosidade, “(...) o indivíduo deve ser considerado pela sociedade ao nível de suas virtualidades e não ao nível de seus atos (...)” (Foucault, 1996b, p. 85), sendo-lhe imputado um julgamento a priori dirigido à possibilidade do acontecimento de um ato infracional. $\mathrm{O}$ perigo de um possível delito é punido antes mesmo de sua concretização. Desse modo, são oferecidas as condições de possibilidade para o soerguimento de uma política repressiva generalizada por parte do Estado imposta à população pobre.

O crime sempre aparece como componente de vida dos pobres e, sob esse argumento, as leis se pautam no discurso da 'prevenção', colocandose como uma forma de ampará-los (...) e fazendo de suas vidas um potencial de crime (Scheinvar, 2002, p. 92, in Nascimento (org.), 2002).

A situação de desprovimento econômico coloca, de antemão, indivíduos e famílias pobres numa situação de irregularidade, tornando-os alvo de ações coercitivas postas em prática pelo Estado e apoiadas por grande parte do segmento da sociedade civil.

Com vista a evitar desvios na ordem social instituída, várias modalidades de saber se prestam à difusão e legitimação de um olhar sob a ótica de uma suposta periculosidade quanto às classes pobres no Brasil. Pedagogia, Medicina, Psicologia, Sociologia e tantas outras disciplinas, muitas vezes, endossam um poder de Estado repressivo sobre a população marginalizada ao atribuir às suas ações intervencionistas um estatuto científico pretensamente verdadeiro.

Em estudo recente, Coimbra (2001) se debruça sobre uma outra modalidade de apropriação das falas e histórias de vida das classes populares, a saber, os discursos de segurança pública veiculados através da mídia impressa no Brasil. Em seu trabalho, a autora desnaturaliza o problema da criminalidade e violência social, vinculando suas origens à emergência de práticas sociais engendradas historicamente. A abordagem por meio desse viés articula-se ao tema aqui proposto na medida em que tais discursos de segurança pública realizam, por um caminho análogo, a estratégia de desqualificação das classes pobres. “As verdades, portanto, são massivamente produzidas em nosso cotidiano por uma série de equipamentos sociais e hoje, ocupando lugar privilegiado, estão os mass media" (Coimbra, 2001, p. 45).

Essa maciça construção de saber e captura dos discursos de pessoas pobres, veiculado de forma estrategicamente perversa pelo recurso da mídia a serviço de poderes hegemônicos, despotencializa - quando não apaga completamente - os discursos proferidos pelas classes populares, relegando-as a um espaço de submissão perante os valores das classes dominantes. 
A memória histórica 'oficial' tem sido produzida pelos diferentes equipamentos sociais no sentido de apagar os vestígios que as classes populares e os opositores vão deixando ao longo de suas experiências de resistência e luta num esforço contínuo de exclusão dessas forças sociais como sujeitos que forjaram e estão forjando também uma outra história, nunca narrada oficialmente. (Coimbra, 2001, p. 51).

Opera-se uma desqualificação não somente individualizante do sujeito pobre mas também de seus hábitos, de suas relações cotidianas e de todo o conhecimento popular que o cerca. Aniquila-se a possibilidade de atenção para outros atributos, pois a atenção está estritamente voltada para o iminente perigo de suas ações.

Posto que "a verdade universal e o direito geral são ilusões ou armadilhas” (Foucault, 1997a, p. 74), torna-se um exercício extremamente interessante investigar quais as possibilidades de ruptura com esse poder hegemônico que as classes populares nos apresentam, em que momentos suas falas são, de fato, autorais, de que modo burlam o intenso controle imposto às suas vidas, por quais caminhos escapam da tutela científica e policial que se lhes impõe e episódios onde seus diferenciados modos de existência escapam ao cerceamento imposto, seja pelos regimentos de saber científico que tornam patológicos seus arranjos de vida, seja pelos discursos de segurança pública que lhes imprimem a marca de um perigo em potencial.

Referenciais distintos sugerem olhares diferenciados. A aliança com a música popular, mais especificamente as composições de Chico Buarque, sem dúvida, oferece-nos interessantes alternativas.

\section{Na Obra do Artista, a Afirmação da Singularidade}

Prostitutas, operários, malandros, crianças criminosas, retirantes nordestinos. Dentre outros, estes são alguns dos personagens que comumente povoam as canções de Chico Buarque. De maneira extremamente sensível, esse artista soube retratar, em inúmeras de suas composições, o cotidiano singelo de histórias de vidas marginalizadas, histórias de vidas desprovidas de grandes acontecimentos, feitos enaltecedores ou fatos grandiosos, histórias de vidas geralmente taxadas de menores, pobres em eventos e até medíocres, por assim dizer. São vidas desinteressantes aos olhos de uma sociedade ávida por realizações espetaculares, por acontecimentos homéricos. No entanto, sob a ótica desse artista, transformam-se em histórias de vidas extremamente potentes, portando desejos, dores, alegrias, paixões, lutas, angústias, enfim, movimentos insubordinadores sob o ponto de vista de um poder central homogeneizador.

Nos acontecimentos ínfimos tecidos na vida diária dos personagens das classes populares, Chico revela a existência de um cotidiano repleto de vida. Por vezes, é um cotidiano comportando dores, dificuldades, mas também pleno em manifestações de regozijo. São acontecimentos banais, fatos simples da vida ordinária de qualquer um, porém suficientes para destruir inapelavelmente teorias e saberes promotores de um olhar através das lentes da falta e da carência para a observação dos arranjos de vida dessas classes.

São histórias que apontam para díspares caminhos, diversos daqueles que procuram enquadrar os indivíduos "segundo sistemas hierárquicos, sistemas de valores e sistemas de submissão - não sistemas de valores visíveis e explícitos, (...), mas sistemas de submissão muito mais dissimulados" (Guattari e Rolnik, 1996, p. 16). À força que impõe modos hegemônicos de se estar no mundo, contrapõemse outras. Insurgem-se, a todo momento, construções de novos modos de existência, constituem-se outros territórios, diferenciados espaços de vida e de afeto (Guattari e Rolnik, 1996, p.14). São experiências singulares que escapam às tentativas de modelização impostas por sistemas majoritários; justo por isso, portam, na sua originalidade, um certo tipo de germe transgressor. A esse movimento, Guattari e Rolnik (1996, p. 17) chamaram de "processo de singularização". Esse conceito diz respeito a:

(...) uma maneira de recusar todos esses modos de encodificação preestabelecidos, todos esses modos de manipulação e de telecomando, recusá-los para construir, de certa forma, modos de sensibilidade, modos de relação com o outro, modos de produção, modos de criatividade que produzam uma subjetividade singular. Uma singularização existencial que coincida com um desejo, com um gosto de viver, com uma vontade de construir o mundo no qual nos encontramos, com a instauração de dispositivos para mudar os tipos de sociedade, os tipos de valores que não são nossos.

Tais processos se revelam mesmo nos acontecimentos mais simples da vida ordinária. Acontecimentos banais e corriqueiros tecidos na vida cotidiana, que, para Heller (2000), é a vida de todo homem, que todos vivem sem exceção, independentemente de seu posto na divisão do trabalho intelectual ou físico, já nascendo nela inserido e sendo invariavelmente heterogênea (Heller, 2000, pp. 17-18). É uma vida cotidiana 
que se apresenta como um campo experimental, repleta de eventos singulares revelados, por exemplo, em algumas composições de Chico sobre os desenlaces do dia a dia dos personagens que compõem as classes populares:

No palco, na praça, no circo, num banco de jardim / Correndo no escuro, pichando no muro / Você vai saber de mim / Mambembe, cigano / Debaixo da ponte, cantando / Por baixo da terra, cantando / Na boca do povo, cantando / Mendigo, malandro, moleque, molambo, bem ou mal / Escravo fugido e louco varrido / Vou fazer meu festival / (...) / Poeta, palhaço, pirata, corisco, errante judeu / Dormindo na estrada, não é nada, não é nada / E esse mundo é todo meu

(Mambembe, 1972).

(...) / Mas o que eu quero é lhe dizer que a coisa aqui tá preta / Muita mutreta pra levar a situação / Que a gente vai levando de teimoso e de pirraça / E a gente vai tomando, que também, sem a cachaça / Ninguém segura esse rojão /(...)/É pirueta pra cravar o ganha-pão / Que a gente vai cavando só de birra, só de sarro / E a gente vai fumando que, também, sem um cigarro / Ninguém segura esse rojão / (...) / Muita careta pra engolir a transação / E a gente tá engolindo cada sapo no caminho / E a gente vai se amando que, também, sem um carinho / Ninguém segura esse rojão /(...)

(Meu caro amigo, em parceria com Francis Hime, 1976).

Quando nasci veio um anjo safado / O chato dum querubim / E decretou que eu tava predestinado / A ser errado assim / Já de saída a minha estrada entortou / Mas vou até o fim / Inda garoto deixei de ir à escola / Cassaram meu boletim / Não sou ladrão, eu não sou bom de bola / Nem posso ouvir clarim / Um bom futuro é o que jamais me esperou / Mas vou até o fim / (...) / Por conta de uma questões paralelas / Quebraram meu bandolim / Não querem mais ouvir as minhas mazelas / E a minha voz chinfrim / Criei barriga, minha mula empacou / Mas vou até o fim / Não tem cigarro, acabou minha renda / Deu praga no meu capim / Minha mulher fugiu com o dono da venda / O que será de mim? / Eu já nem lembro pronde mesmo que vou / Mas vou até o fim /(...)

(Até o fim, 1978).

(...) / Sambando na lama de sapato branco, glorioso / Um grande artista tem que fazer fé / Quase rodando, caindo de boca / Aba de touca, jura de mulher / Sambando na lama e passando o boné / (...) / Cantando e sambando na lama de sapato branco, glorioso / Um grande artista tem que dar o que tem e o que não tem / Tocando a bola no segundo tempo / Atrás de tempo, sempre tempo vem / Sambando na lama, amigo, e tudo bem / (...)
/ Sambando na lama de sapato branco, glorioso / Um grande artista tem que estar feliz / Sambando na lama e salvando o verniz / (...)

(Cantando no toró, 1987).

São vidas que, através das letras de Chico, afirmam sua existência mesmo nas condições mais insólitas, deflagrando suas tortas desventuras, mostrando sua potencialidade no relato autoral de suas experiências; vidas, como afirma Lobo (1997), sem qualquer notoriedade, sem nenhum valor ou qualquer feito glorioso, fadadas a desaparecerem no tempo sem deixar qualquer rastro (Lobo, 1997, p. 01). São, ainda assim, experiências que comportam uma riqueza e uma complexidade ímpares no enredo de seus frívolos descaminhos, vidas que, mesmo marginalizadas, pulsam com extraordinário vigor, independentemente do papel encenado nas relações sociais.

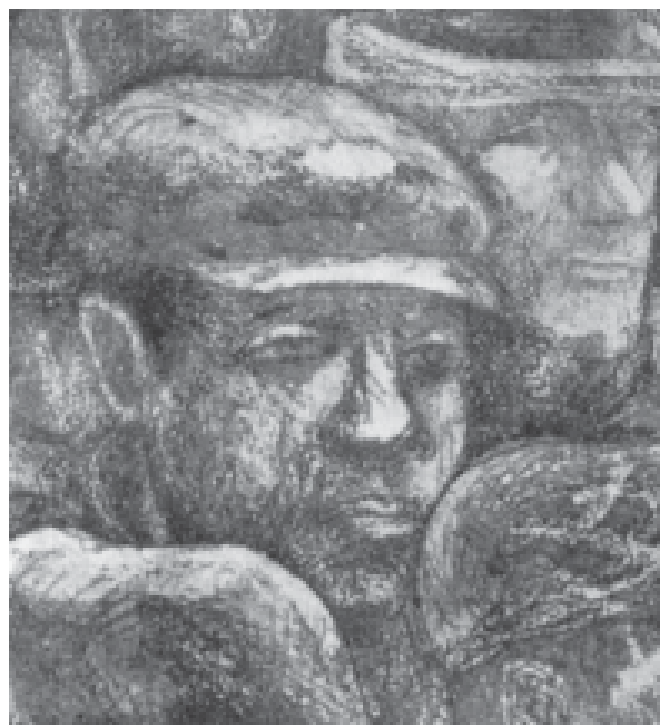

São vidas que, através das letras de Chico, afirmam sua existência mesmo nas condições mais insólitas, deflagrando suas tortas

desventuras, mostrando sua potencialidade no relato autoral de suas experiências; vidas, como afirma Lobo (1997), sem qualquer notoriedade, sem nenhum valor ou qualquer feito glorioso, fadadas a desaparecerem no tempo sem deixar qualquer rastro

\section{Lobo}

São existências marginais, sobrevivendo paralelamente à ordem econômica e social hegemônica vigente. "Os invisíveis da história e que, no entanto, sempre estiveram lá (...)” (Lobo, 1997, p. 01), personagens estigmatizados: vagabundos, mulheres de vida reles, crianças infratoras, retirantes nordestinos, prostitutas, malandros, enfim, desvalidos de toda ordem. Apesar da posição socialmente marginalizada onde se encontram relegados, no entanto, são personagens propondo modos singulares de falar sobre si, o mundo em que vivem, os acontecimentos cotidianos que os rodeiam e os múltiplos sentidos que estes possam desencadear, vidas teimando em apontar que, na simplicidade das pequenas coisas, pode haver muita riqueza:

(...) / Já brinquei de bola / Já soltei balão / Mas tive que fugir da escola / Pra aprender essa lição / (...) / 
Deixa de feitiço / Que eu não mudo não / Pois eu sou sem compromisso / Sem relógio e sem patrão / (...) / Eu nasci sem sorte / Moro num barraco / Mas meu santo é forte / E o samba é meu fraco / No meu samba eu digo / O que é de coração (Meu refrão, 1965).

(...) / Jesus Cristo inda me paga, um dia inda me explica / Como é que pôs no mundo esta pobre coisica (pouca titica*) / Vou correr o mundo afora, dar uma canjica / Que é pra ver se alguém se embala ao ronco da cuíca / E aquele abraço pra quem fica / Deus me fez um cara fraco, desdentado e feio / Pele e osso simplesmente, quase sem recheio / Mas se alguém me desafia e bota a mãe no meio / Dou pernada a três por quatro e nem me despenteio / Que eu já tô de saco cheio / Deus me deu mão de veludo pra fazer carícia / Deus me deu muitas saudades e muita preguiça / Deus me deu pernas compridas e muita malícia / Pra correr atrás de bola e fugir da polícia / Um dia ainda sou notícia (Partido alto, 1972) *termo original vetado pela censura.

Quando, seu moço, nasceu meu rebento / Não era o momento dele rebentar / Já foi nascendo com cara de fome / E eu não tinha nem nome pra lhe dar / Como fui levando, não sei lhe explicar / Fui assim levando ele a me levar / E na sua meninice ele um dia me disse / Que chegava lá / (...) / Chega suado e veloz do batente / E traz sempre um presente pra me encabular / Tanta corrente de ouro, seu moço / Que haja pescoço pra enfiar / Me trouxe uma bolsa já com tudo dentro / Chave, caderneta, terço, patuá / Um lenço e uma penca de documentos / Pra finalmente eu me identificar, olha aí / (...) / Chega no morro com o carregamento / Pulseira, cimento, relógio, pneu, gravador / Rezo até ele chegar cá no alto / Essa onda de assaltos tá um horror / Eu consolo ele, ele me consola / Boto ele no colo pra ele me ninar / De repente acordo / Olho pro lado / E o danado já foi trabalhar, olha aí / (...) / Chega estampado, manchete, retrato / Com venda nos olhos, legenda e as iniciais / Eu não entendo essa gente, seu moço / Fazendo alvoroço demais / O guri no mato, acho que tá rindo / Acho que tá lindo de papo pro ar / Desde o começo, eu não disse, seu moço / Ele disse que chegava lá / (...) (O meu guri, 1981).

Perdida / Na avenida / Canta seu enredo / Fora do carnaval / Perdeu a saia / Perdeu o emprego / Desfila natural / Esquinas / Mil buzinas / Imagina orquestras / Samba no chafariz / Viva a folia / A dor não presta / Felicidade, sim / (...) / Bambeia / Cambaleia / É dura na queda / Custa a cair em si / Largou a família / Bebeu veneno / E vai morrer de rir / Vagueia / Devaneia / Já apanhou a beça / Mas para quem sabe olhar / A flor também é / Ferida aberta / E não se vê chorar/(...)

(Dura na queda (ela desatinou $\left.\left.n^{\circ} 2\right), 2000\right)$.
Há, ainda, na obra de Chico, personagens que não habitam especificamente o plano da marginalidade. São personagens que não burlam as regras do jogo social instituído. São operários e trabalhadores urbanos ou rurais, figuras inseridas na ordem do sistema de produção capitalista, personagens que se encontram em uma condição econômica e social claramente subalterna, mas nem por isso deixam de afirmar a riqueza e a potencialidade contida em seus triviais discursos:

(...) / Quando a sirene não apita / Ela acorda mais bonita / Sua pela é sua chita, seu fustão / E, bem ou mal, é o seu veludo / É o tafetá que Deus lhe deu / E é bendito o fruto do suor / Do trabalho que é só seu $/(\ldots)$

(Primeiro de maio, em parceria com Milton Nascimento, 1977).

Vivo de biscate e queres que eu te sustente / Se eu ganhar algum vendendo mate / Dou-te uns badulaques de repente / Andas de pareô, eu sigo inadimplente / (...) Vives na gandaia e espera que eu te respeite / Quem que te mandou tomar conhaque / Com o tíquete que te dei pro leite / Quieta que eu quero ouvir Flamengo e River Plate / (...)

(Biscate, 1993).

Como então? Desgarrados da terra? / Como assim? Levantados do chão? / Como embaixo dos pés uma terra / Como água escorrendo da mão? / Como em sonho correr numa estrada? / Deslizando no mesmo lugar? / Como em sonho perder a passada / E no oco da terra tombar? / (...) / Ou na planta dos pés uma terra / Como água na planta da mão? / Habitar uma lama sem fundo? / Como em cama de pó se deitar? / Num balanço de rede sem rede / Ver o mundo de pernas pro ar? / (...)

(Levantados do chão, em parceria com Milton Nascimento, 1997).

Iracema voou / Para a América / Leva roupa de lã / E anda lépida / Vê um filme de quando em vez / Não domina o idioma inglês / Lava chão numa casa de chá / Tem saído ao luar / Com um mímico / Ambiciona estudar / Canto lírico / Não dá mole pra polícia / Se puder, vai ficando por lá / Tem saudade do Ceará / Mas não muita / Uns dias afoita / Me liga a cobrar: / - É Iracema da América

(Iracema voou, 1998).

Encontramos, também, a exaltação dessa potencialidade de vida nas composições de Chico sobre o cotidiano da vida conjugal entre personagens das classes populares. Relacionamentos amorosos que, à luz de alguns referenciais majoritários de saber, deveriam submeter-se a técnicas elaboradas de fazer e agir, cuja finalidade seria priorizar os bons costumes, a boa conduta e o combate à promiscuidade, um 
saber que, além de produzir subjetividades, produziria também modos corretos e seguros de comportamentos afetivos. Observamos, na seleção de composições a seguir, relacionamentos que, sob a ótica de um poder central, bem deveriam ser taxados de incorretos, libertinos, relacionamentos nos quais, apressadamente, poderíamos pressupor haver somente dor e sofrimento. Porém, sob a ótica do artista e apesar de todas as dificuldades financeiras, são encontros preenchidos por exaltações de afeto e carinho singulares, nem um pouco menores ou menos dignos que o amor pautado no modelo conservador burguês:

A Rita levou meu sorriso / (...)/Levou seu retrato, seu trapo, seu prato / Que papel! / Uma imagem de São Francisco / E um bom disco de Noel / (...) / Nem herança deixou / Não levou um tostão / Porque não tinha não / Mas causou perdas e danos / (...)

(A Rita, 1965).

(...) / O meu samba se marcava na cadência dos seus passos / O meu sono se embalava no carinho dos seu braços / Hoje de teimoso eu passo bem em frente ao seu portão / Pra lembrar que sobra espaço no barraco e no cordão / (...) / Todo ano eu lhe fazia uma cabrocha de alta classe / De dourado eu lhe vestia pra que o povo admirasse / (...)

(Quem te viu, quem te vê, 1966).

Você não ouviu / O samba que eu lhe trouxe / Ai, eu lhe trouxe rosas / Ai, eu lhe trouxe um doce / As rosas vão murchando / E o que era doce acabou-se / Você me desconcerta / Pensa que está certa / Porém não se iluda / No fim do mês, quando o dinheiro aperta / Você corre esperta / E vem pedir ajuda / (...)

(Você não ouviu, 1966).

Amando noites afora / Fazendo a cama sobre os jornais / Um pouco jogados fora / Um pouco sábios demais / Esparramados no mundo / Molhamos o mundo com delícias / As nossas peles retintas / De notícias / Amando noites a fio / Tramando coisas sobre os jornais / Fazendo entornar um rio / E arder os carnavais / Das páginas flageladas / Sorrimos, mãos dadas e, inocentes / Lavamos os nossos sexos / Nas enchentes / Amando noites afundo / Tendo jornais como cobertor / Podendo abalar o mundo / No embalo do nosso amor / No ardor de tantos abraços / Caíram palácios / Ruiu um império / Os nossos olhos vidrados / De mistério

(Amando sobre os jornais, 1979).

Quando nos apaixonamos / Poça d'água é chafariz / Ao olhar o céu de Ramos / Vejo as luzes de Paris / No verão é uma delícia / A brisa fresca de Bangu / Mesmo um cabo de polícia / Só nos diz merci beaucoup / Eu ouço um samba de breque / Com Maurice Chevalier / Bebo com Toulouse-Lautrec / No bar Caxinguelê /
Daí ninguém mais estranha / O Louvre na Praça Mauá / E o borbulhar da champanha / Num gole de guaraná / Cascadura é Rive Gauche / O mangue é Champs Elysées / Até mesmo um bate-coxa / Faz lembrar um pas-de-deux / Purê de batata roxa / Parece marrom glacé

(Canção de Pedroca, 1979).

Casa de João de Rosa / Rosa de João / João que levantou a casa / No boqueirão / João que fez aquela casa / Rosa fez questão / A casa de botão de Rosa / Que é de João / Rosa aconchegou a casa / Casa de joão-debarro, a concha cor-de-rosa / Não tem portão / João mandou fazer pra Rosa / Forro de alcatrão / Ninguém jamais entrou na casa / Que é de João / Roda Rosa pela casa / Coisa de João / João foi quem ensinou a Rosa / Rolar no chão / João cheirando aquela Rosa / Goza de antemão / E Rosa, amando aquela casa / Rega João

(Casa de João de Rosa, em parceria com Edu Lobo, 1988).

Pelo viés das composições de Chico Buarque e os percursos díspares de suas histórias de vidas marginais, podemos explorar as contribuições de Guattari e Rolnik (1996) sobre os processos de singularização ${ }^{1}$. Segundo os autores, o que caracteriza esse processo de singularização exercitado pelas classes populares é o seu caráter automodelador:

Isto é, que ele capte os elementos da situação, que construa seus próprios tipos de referências teóricas, sem ficar nessa posição constante de dependência em relação ao poder global, em nível econômico, em nível do saber, em nível técnico, em nível das segregações, dos tipos de prestígios que são difundidos. A partir do momento em que os grupos adquirem essa liberdade de viver seus processos, eles passam a ter uma capacidade de ler sua própria situação e aquilo que se passa em torno deles. Essa capacidade é que vai lhes dar um mínimo de possibilidade de criação e permitir preservar exatamente esse caráter de autonomia tão importante (Guattari e Rolnik, 1996, p. 46).

Às tentativas de controle social irrestrito por parte de um poder de Estado centralizador, opõem-se modos específicos de resistências. A fim de conceituar a relutância de determinados grupos sociais em curvarem-se aos modelos hegemônicos de produção de subjetividades e, concomitantemente a esse combate, a invenção de múltiplas formas de sociabilidades, Guattari cunhou o termo revolução molecular.

O que caracteriza os novos movimentos sociais não é somente uma resistência contra esse processo geral de serialização da subjetividade, mas também a tentativa de produzir modos de subjetividade
A fim de conceituar a relutância de determinados grupos sociais em curvaremse aos modelos hegemônicos de produção de subjetividades $e$, concomitantemente a esse combate, a invenção de múltiplas formas de sociabilidades, Guattari cunhou o termo revolução molecular.

1 Segundo Guattari e Rolnik (1996, p. 47), por 'processo de singularização' entende-se a constituição de "algo que pode conduzir à afirmação de valores num registro particular, independentemente das escalas de valor que nos cercam e espreitam de todos os lados." 
originais e singulares, processos de singularização subjetiva (...) A revolução molecular consiste em produzir as condições não só de uma vida coletiva, mas também da encarnação da vida para si próprio, tanto no campo material, quanto no campo subjetivo (Guattari e Rolnik, 1996, p. 45-46).

As relações que se estabelecem, a partir do embate entre as tentativas de captura dos discursos das classes populares e as estratégias de escape implementadas por estas, de maneira alguma são definitivas. Tais relações se dão a partir de um jogo de forças desenhado conforme as múltiplas direções apontadas por esses embates, afirmando, assim, a condição inconclusa dessas lutas. Atribuir uma conotação libertária a essas microrrevoluções só é possível se mediada pela compreensão de seu caráter processual, ou seja, como uma luta jamais vencida, mas também jamais perdida, e, sim, engendrada diariamente, construída e reconstruída cotidianamente, nunca acabada.

Afirmando a singularidade de suas experiências através das composições de

Chico, esses personagens realizam um duplo

feito: exercitam constantemente o escape às tentativas de normatização exercidas por um poder totalizador, $e$, simultaneamente, potencializam a intensidade de suas experiências cotidianas mesmo nas condições menos favorecidas.

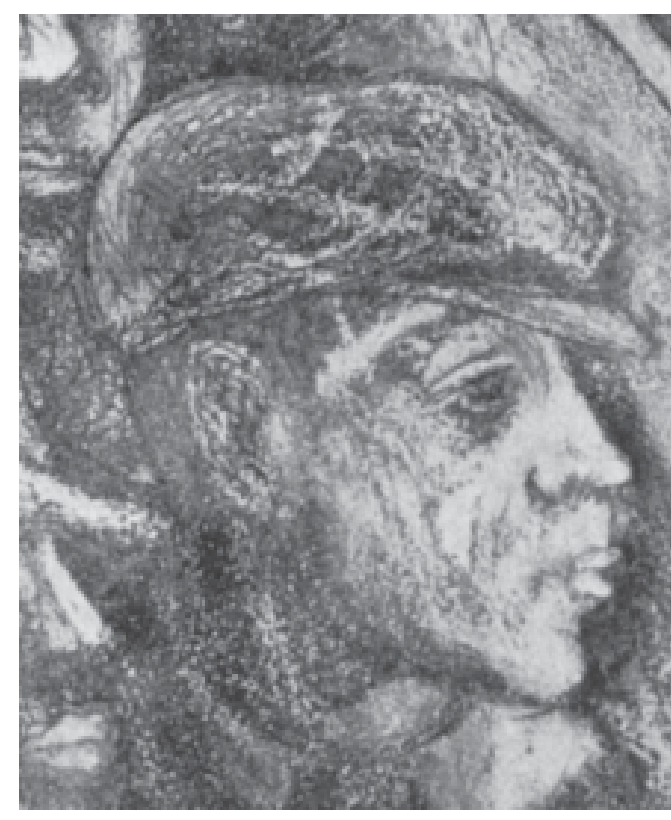

Afirmando a singularidade de suas experiências através das composições de Chico, esses personagens realizam um duplo feito: exercitam constantemente o escape às tentativas de normatização exercidas por um poder totalizador, e, simultaneamente, potencializam a intensidade de suas experiências cotidianas mesmo nas condições menos favorecidas. As composições a seguir trazem à luz o grau elevado desses embates. São exemplos onde os personagens das classes populares reconhecem as intempéries de suas existências marginalizadas, a dor do golpe de uma força opressora; contudo, reagem exaltando a dignidade de seu sofrimento, afirmando a vida por meio de suas lutas diárias:
Há muito tempo / Que essa minha gente / Vai vivendo a muque / É o mesmo batente / É o mesmo batuque / (...) / A minha nega me pediu um vestido / Novo e colorido / Pra comemorar / Eu disse: / Finja que não está descalça / Dance alguma valsa / Quero ser seu $\operatorname{par} /(\ldots)$

(Ano novo, 1967).

Tem certos dias / Em que eu penso em minha gente / E sinto muito / Todo o meu peito se apertar / Porque parece / Que acontece de repente / Feito um desejo de eu viver / Sem me notar / Igual a como / Quando eu passo no subúrbio / Eu muito bem / Vindo de trem de algum lugar / E aí me dá / Como uma inveja dessa gente / Que vai em frete / Sem nem ter com quem contar / São casas simples / Com cadeiras na calçada / E na fachada / Escrito em cima que é um lar / Pela varanda / Flores tristes e baldias / Como a alegria / Que não tem onde encostar / $E$ aí me dá uma tristeza / No meu peito / Feito um despeito / De eu não ter como lutar / E eu que não creio / Peço a Deus por minha gente / É gente humilde / Que vontade de chorar

(Gente humilde, em parceria com Garoto e Vinícius de Morais, 1969).

Por esse pão pra comer, por esse chão pra dormir / A certidão pra nascer, e a concessão pra sorrir / Por me deixar respirar, por me deixar existir / Deus lhe pague / Pelo prazer de chorar e pelo "estamos aí" / Pela piada no bar e o futebol pra aplaudir / Um crime pra comentar e um samba pra distrair / Deus lhe pague / Por essa praia, essa saia, pelas mulheres daqui / O amor malfeito depressa, fazer a barba e partir / Pelo domingo que é lindo, novela, missa e gibi / Deus lhe pague / Pela cachaça de graça que a gente tem que engolir / Pela fumaça, desgraça, que a gente tem que tossir / Pelos andaimes, pingentes, que a gente tem que cair / Deus lhe pague / Por mais um dia, agonia, par suportar e assistir / Pelo rangido dos dentes, pela cidade a zunir / E pelo grito demente que nos ajuda a fugir / Deus lhe pague / Pela mulher carpideira pra nos louvar e cuspir / E pelas moscas-bicheiras a nos beijar e cobrir / E pela paz derradeira que enfim vai nos redimir / Deus lhe pague (Deus lhe pague, 1971).

(...) / Se te dói o corpo / Diz que sim / Torcem mais um pouco / Se te dão um soco / Diz que sim / Se te deixam louco / Diz que sim / Se te babam no cangote / Mordem o decote / Se te alisam com o chicote / Olha bem pra mim / Vence na vida quem diz sim / Vence na vida quem diz sim / Se te jogam lama / Diz que sim / Pra que tanto drama / Diz que sim / Te deitam na cama / Diz que sim / Se te criam fama / Diz que sim / Se te chamam vagabunda / Montam na cacunda / Se te largam moribunda / Olha bem pra mim / Vence na vida quem diz sim / Vence na vida quem $\operatorname{diz} \operatorname{sim} /(\ldots)$

(Vence na vida quem diz sim, em parceria com Ruy Guerra, 1973). 
$E$ se, de repente / A gente não sentisse / A dor que a gente finge / E sente / Se, de repente / A gente distraísse / O ferro do suplício / Ao som de uma canção / Então, eu te convidaria / Pra uma fantasia / Do meu violão / (...)

(Fantasia, 1978).

Se tu falas muitas palavras sutis / E gostas de senhas, sussurros, ardis / A lei tem ouvidos pra te delatar / Nas pedras do teu próprio lar / Se trazes no bolso a contravenção / Muambas, baganas e nem um tostão / A lei te vigia, bandido infeliz / Com seus olhos de raio- $\mathrm{X}$ / Se vives nas sombras, freqüentas porões / Se tramas assaltos ou revoluções / A lei te procura amanhã de manhã / Com seu faro de dobermann / E se definitivamente a sociedade só te tem / Desprezo e horror / E mesmo nas galeras és nocivo / És um estorvo, és um tumor / A lei fecha o livro, te pregam na cruz / Depois chamam os urubus / Se pensas que burlas as normas penais / Insuflas, agitas e gritas demais / A lei logo vai te abraçar, infrator / Com seus braços de estivador / (...)

(Hino de Duran, 1979).

A novidade / Que tem no Brejo da Cruz / É a criançada / Se alimentar de luz / Alucinados / Meninos ficando azuis / E desencarnado / Lá no Brejo da Cruz /Eletrizados / Cruzam os céus do Brasil / Na rodoviária / Assumem formas mil / Uns vendem fumo / Têm uns que viram Jesus / Muito sanfoneiro / Cego tocando blues / Uns têm saudade / E dançam maracatus / Uns atiram pedra / Outros passeiam nus / Mas há milhões desses seres / Que se disfarçam tão bem / Que ninguém pergunta / De onde essa gente vem / São jardineiros / Guardas noturnos, casais / São passageiros / Bombeiros e babás / (...) / São faxineiros / Balançam nas construções / São bilheteiras / Baleiros e garçons / (...)

(Brejo da Cruz, 1984).

Muito embora a intenção deste trabalho seja ressaltar a originalidade e a produção autoral dos discursos advindos das classes populares, não desejamos atribuir uma conotação de protesto às composições de Chico. Procuramos distanciar-nos de uma análise que interprete essa seleção de letras tão somente como um lamento ou uma queixa, enfim, como se essas narrativas rogassem por clemência, pronunciassem suas lamúrias contra um sistema econômico-social perverso e excludente e um poder de Estado violento e segregador, como se o artista estivesse tão-somente a emprestar sua voz a figuras malditas que reclamam seu lugar ao sol. Não se trata disso. Visamos apostar numa outra via: a da potência contida no cotidiano dessas histórias de vidas, apesar de marginalizadas.

São vidas contadas a partir de uma perspectiva genealógica. Para Foucault, descrever os acontecimentos sob a perspectiva de uma gênese linear apazigua os fatos históricos, pois privilegia, invariavelmente, o registro histórico a partir da ótica das classes detentoras do poder em todas as suas esferas:

(...) como se esse mundo de coisas ditas e queridas não tivesse conhecido invasões, lutas, rapinas, disfarces, astúcias. Daí, para a genealogia, um indispensável demorar-se: marcar a singularidade dos acontecimentos, longe de toda finalidade monótona; espreitá-los lá onde menos se os esperava e naquilo que é tido como não possuindo história - os sentimentos, o amor, a consciência, os instintos (...) (Foucault, 1996a, p. 15).

Na exposição de seus relatos mais próprios, mesmo ásperos, mesmo sofridos, são cotidianos revelando que a vida lateja com energia até nas condições mais insuspeitas. Tais vidas nada reclamam, mas afirmam sua existência por meio daquilo que lhes é mais próprio: sua presença no mundo.

\section{Considerações Finais}

Frente aos modos historicamente produzidos e contemporaneamente reeditados de opressão às classes populares, que possibilidades de resistência podem ser vislumbradas? Em meio a um mundo regido pela modelagem de comportamentos e condutas, quais as alternativas para expressar autenticidade nos modos e experiências de vida? Seguramente, diferenciadas formas de se fazer presente no mundo existem e são plenamente possíveis. Alianças podem ser compostas e recompostas a todo o instante, brechas aguardam o momento de serem exploradas; a parceria com a arte, com a música popular, é somente uma delas.

(...) por toda parte, observamos estratégias e mecanismos presentes em diversos grupos, movimentos que conseguem, algumas vezes, reverter tais produções hoje hegemônicas. Tais processos de singularização são respostas que se nos apresentam e que evidenciam como tem sido possível forjar outras percepções, outras formas de se relacionar, outros modos de vida e existência no plano micropolítico. Movimentos, muitas vezes, invisíveis, microscópicos, mas que, silenciosamente, subterraneamente, estão produzindo outras realidades e verdades, outras histórias e memórias (Coimbra, 2001, p. 74-75).

Diante dos movimentos de captura e despotencialização dos discursos das classes populares, existem, indubitavelmente, modalidades infinitas de escape e resistência. Definitivamente, não estamos imersos em uma fatalidade. A potência contida na vida diária da massa de desvalidos exemplificada nas letras de Chico Buarque assim 
o prova. Não são modos cristalizados, previamente elaborados de se lidar com um poder opressor; são estratégias múltiplas de combate, inventadas e renovadas a cada dia, forjadas ao sabor do ineditismo das situações, inseridas no campo indefinido da História.

De maneira a preservar a intensidade autoral de seus relatos, privilegiamos a transcrição literal de uma pequena amostra das composições de Chico Buarque. Nelas, por meio de sua autenticidade própria, inúmeras vidas sem fama imprimem sua passagem pelo mundo mediada pela narrativa de seus feitos inglórios, de suas histórias sem heroísmo, de suas batalhas sem vitórias, afirmando a vida sob quaisquer condições. Nada há a ser interpretado, porém muito a ser escutado. São histórias de vida extremamente próprias, cada qual portando, em sua trajetória, uma peculiar riqueza, admitindo uma infinidade de sentidos, histórias que expõem a beleza trágica do cotidiano, o passado, o presente e o futuro esquecido de lutas reais, exibindo a poesia contida no dia a dia de formas de vida malnascidas.

Contudo, apesar do caráter de singularidade que portam, todas elas possuem algo em comum: atrevem-se a contrariar quaisquer modos preestabelecidos de compreensão acerca de seus atuais arranjos ou de seus destinos, questionando, contundentemente, regimentos de saber e aparatos de poder historicamente produzidos para tutelálas. Por meio do simples relato de seus afazeres cotidianos, tais histórias desmontam, inapelavelmente, toda a enganosa construção de conhecimento feita sobre essas vidas, construção histórica pautada em modelos de racionalidade científica de cunho eminentemente preventivista e segregador, “(...) racionalidade que, na medida em que se sobe e em que ela se desenvolve, tornase cada vez mais frágil, cada vez mais malvada, cada vez mais ligada à ilusão, à quimera, à mistificação” (Foucault, 1997a, p. 75).
Ao criar um número sem fim de personagens reles, donos de vidas infelizes, Chico revela algo além da marca singular que essas vidas comportam. Narrando a saga de suas trajetórias, a desventura de seus tortos caminhos, o artista oferece a condição para que essas vozes se manifestem, bradando elas mesmas a autoria de seus feitos. O simples fato de falar sobre suas vidas, demonstrando os múltiplos sentidos que elas podem comportar, já se constitui em uma valiosa estratégia de combate. No entanto, isso não quer dizer que, em suas composições, o artista fale pelas classes populares, posto que todo ato de se falar pelo e para o outro representa uma impostura, mas, sim, elas falam mediadas pela obra do artista, como uma multidão de vozes entoando seu alarido, seu clamor de combate, por meio de uma, apenas. Criada a condição para que essas vozes se manifestem, novas possibilidades de escuta desses discursos são oferecidas, fazendo emergir outros sentidos. Tais possibilidades são diferenciadas daquelas que marcam os sujeitos com as cicatrizes da falta e da carência, desqualificando suas vidas, despotencializando seus discursos.

Por meio da obra de Chico Buarque, é possível a construção de outros olhares sobre os desenlaces da vida cotidiana dos sujeitos que compõem as classes populares no Brasil. Nas composições selecionadas, subverte-se o favorecimento dado pela história oficial em narrar a história dos vencedores em detrimento da história dos vencidos, e interroga-se a noção naturalizada e pejorativa a respeito desses personagens que os discursos majoritários procuram disseminar. Na obra do artista, vidas são potencializadas em seus percursos singulares, em seus acontecimentos minúsculos, vidas não mais sobrepujadas, carentes ou desqualificadas, mas permeadas de paixões, carregadas de júbilo, abarrotadas de desejos. Mesmo marcadas por suas turvas existências, são vidas que deixaram, legitimamente, os vestígios de sua passagem pelo mundo.

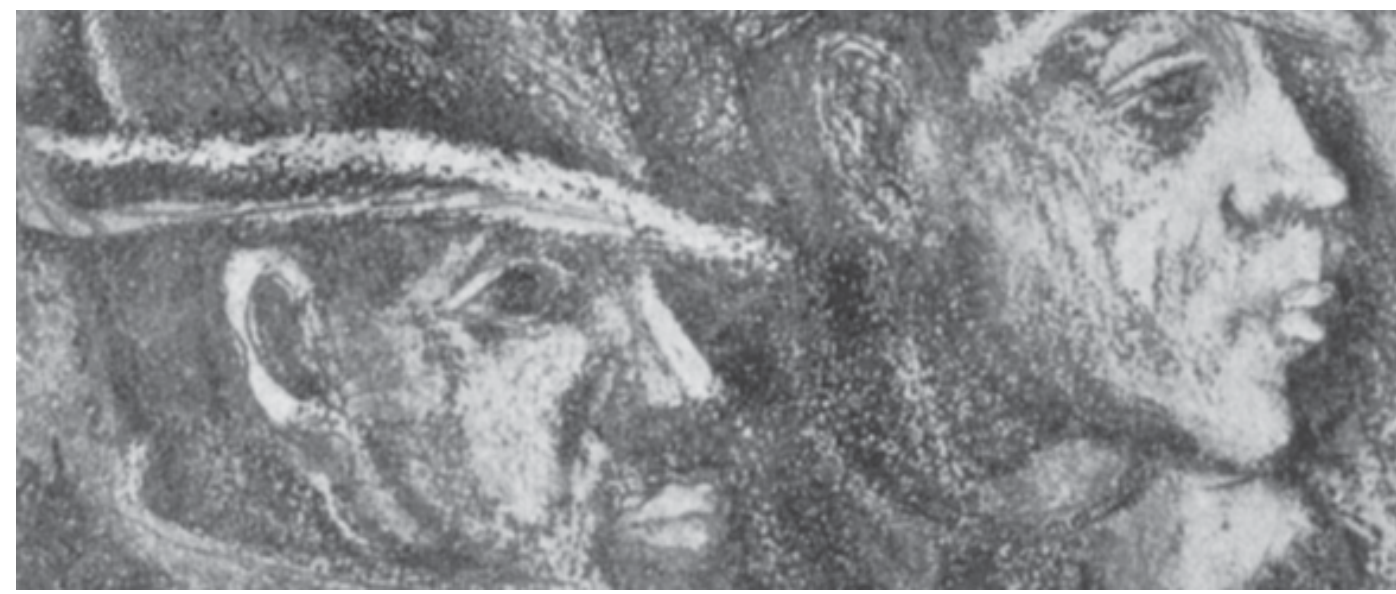


BAPTISTA, L. A. A Cidade dos Sábios. Reflexões Sobre a Dinâmica Social nas Grandes Cidades. São Paulo: Summus, 1999.

COIMBRA, C. Operação Rio: o Mito das Classes Perigosas. Um Estudo Sobre a Violência Urbana, a Mídia Impressa e os Discursos de Segurança Pública. Rio de Janeiro: Oficina do Autor; Niterói: Intertexto, 2001.

COSTA, J. F. Ordem Médica e Norma Familiar. Rio de Janeiro: Graal, 1979.

FOUCAULT, M. Nietzsche, a Genealogia e a História. In Microfísica do Poder. Rio de Janeiro: Graal, 1996a.

$1996 \mathrm{~b}$

A Verdade e as Formas Jurídicas. Rio de Janeiro: NAU,

Resumo dos Cursos do Collège de France (1970 1982). Rio de Janeiro: Jorge Zahar Ed., 1997a.

História da Sexualidade I: a Vontade de Saber. Rio de Janeiro: Graal, 1997b.

. A Vida dos Homens Infames. In O que É um Autor. Lisboa: Passagens, 1992.
GUATTARI, F.; ROLNIK, S. Micropolítica: Cartografias do Desejo. Petrópolis: Vozes, 1996.

Referências

HELLER, A. O Cotidiano e a História. São Paulo: Paz e Terra, 2000.

LOBO, L. Os Infames da História: a Instituição das Deficiências no Brasil. Dissertação de Doutorado em Psicologia - PUC, Rio de Janeiro, 1997.

MACHADO, R. et al. Danação da Norma: Medicina Social e Constituição da Psiquiatria no Brasil. Rio de Janeiro: Graal, 1978.

MATOS, C. Acertei no Milhar: Malandragem e Samba no Tempo de Getúlio. Rio de Janeiro: Paz e Terra, 1982.

NASCIMENTO, M. L. (org) Pivetes: a Produção de Infâncias Desiguais. Rio de Janeiro: Oficina do Autor; Niterói: Intertexto, 2002.

NOVAES, J. Luto e Melancolia na Música Popular Brasileira-Nelson Cavaquinho. Dissertação de Doutorado em Comunicação UFRJ, Rio de Janeiro, 1999.

ZAPPA, Regina. Chico Buarque: Para Todos. Rio de Janeiro: Relume Dumará, 2000. 